\title{
Literature of Acquisitions in Review, 2012-13
}

\section{Angela Dresselhaus}

The acquisitions literature published in 2012-13 shows a strong focus on nontraditional purchasing models, especially for electronic books (e-books). Patron Driven Acquisition (PDA) is one method that helps librarians cope with budget constraints that continue to plague library budgets. The expense of Big Deals has some libraries seeking more efficient alternatives such as Pay-Per-View or Evidence-Based Selection, however, many libraries are still reliant on the depth of coverage and perceived value of Big Deals. This review will cover these trends along with developments in Electronic Resources Management Systems (ERMSs), workflow efficiencies, and negotiation and licensing techniques.

T ibrary Resources \& Technical Services has published four prior reviews of acquisitions literature covering the period between 1996 and 2011. ${ }^{1}$ This installment covers literature published in 2012-13. Dunham and Davis noted that the literature published from 1996 to 2003 reflects an environment seriously disrupted by the implementation of automated systems and the Internet, requiring acquisitions departments to move from paper systems to automated library systems. Print acquisitions job responsibilities were restructured to accommodate electronic resource management. In 2004-7, Dunham and Davis observed that electronic journal (e-journal) purchasing was well underway and becoming increasingly complex, necessitating the development of electronic resource management tools. Harrell characterized 2008-9 as driven by budget reductions with the transition of subscriptions from print to electronic collections. The role of the Big Deal was questioned as library budgets decreased and employee skill sets continued to shift to accommodate electronic publications, especially in the area of negotiation and licensing. Moeller noted that budget constraints continued to shape the literature, which is evident in the interest in Open Access and Patron-Driven Acquisitions (PDA), and the increasing scrutiny of Big Deals. For the current review period, budget constraints continue to shape the conversation, causing librarians to question the long-term sustainability of big journal deals, seek consortial-level PDA plans to share costs, and implement open source electronic resource management tools instead of subscription based solutions.

Angela Dresselhaus (dresselhausa15@ ecu.edu) is Head of Electronic Resources at East Carolina University.

Manuscript submitted September 24 2015; returned to author November 20, 2015 to revise; revision submitted January 19, 2016; returned to author March 1, 2016 for minor revisions; revised manuscript submitted March 10, 2016; paper accepted April 1, 2016.

The author would like to acknowledge the hard work of Kimberly Swanson, a diligent and thoughtful research assistant.

\section{Method}

The author replicated the research method described in Moeller's 2010-11 literature review. ${ }^{2}$ A search in Library and Information Science Abstracts (LISA), Web of Science (WOS), and Worldcat.org was conducted using the keywords: library and acquisitions. The date range for each search was limited to materials published in 2012-13. Materials were further filtered to only include scholarly materials published in English. The LISA search yielded 544 results, the WOS search yielded 57 results, and the Worldcat.org search yielded 134 results. Selected 
journals and conference proceedings from the Charleston Conference and the North American Serials Interest Group (NASIG) meetings were systematically reviewed for inclusion in this literature review. The author struggled to find a clear distinction between acquisitions literature and literature covering collection development and e-resources. Despite this challenge, papers focused on purchasing models, supporting workflows, and acquisitions management tools were selected. Papers covering public libraries, secondary school libraries, collection management studies, and gift acquisitions were excluded from this literature review.

\section{Literature Review}

The materials considered for this review are primarily peerreviewed papers, along with relevant columns, interviews, trade publications, conference proceedings, and monographs.

\section{Purchasing Models}

\section{Firm Orders}

Few studies pertaining to monographic firm orders were published during 2012-13. Tony G. Horava, associate university librarian, Collections, at the University of Ottawa wrote a case study documenting the implementation of a new firm order monographic process using the vendor YBP. ${ }^{3}$ Horava noted that a user-centered approach to monographic acquisitions requires that the library develop a workflow to quickly deliver requested books. Economic pressures require that the library use financial and human resources efficiently, reducing the amount of staff involved in fulfillment. In response to these pressures, the librarians at the University of Ottawa decided to implement newly released YBP features to streamline order fulfillment. Advancements in technology allowed the library to partner with YBP to create a more efficient monograph firm order process. Implementing a direct ordering method in YBP reduced fulfillment time for monograph purchases and freed librarians to focus on more complex electronic resource purchases. Horava concluded that the case study was successful, as the library was able to realize a one-week reduction to shelf time for books, acquisitions budget balances were readily available, and time saved by streamlining firm order processing was invested into the management of e-resources.

Rita Cauce, head of the Resource Development Department, Florida International University, discussed the development of an electronic monograph request system that replaced a paper request system. ${ }^{4}$ The system was named Online Library Acquisitions System (OLAS), and was designed to replace a paper-based tracking system used to manage firm order purchase requests. The electronic system was designed to allow librarians to quickly determine the status of an order before it was entered into the ILS. Cauce determined that OLAS improved efficiencies and increased accountability within the acquisitions unit.

\section{Approval Plans}

In previous years, approval plan management was challenged by publication delays that often existed between print and electronic monographs, which complicated combining print and electronic acquisition profiles. Forzetting, Wiersma, and and Eager demonstrated that a partnership between library vendors and librarians was essential for developing comprehensive approval plans built on careful profiling and meticulous tracking of all library monographic purchases. ${ }^{5}$ The most compelling points detail how the librarians and vendor representatives incorporated the established PDA models into the print approval plan workflow and how they accommodated the sometimes disparate electronic and print publication dates. In a separate publication, Wiersma developed a study to determine publication date differences between electronic and print format. ${ }^{6}$ Wiersma found that the publication gap has closed dramatically to the point that in 2011 many publishers had moved to simultaneous print and electronic publication. Wiersma also analyzed publisher and subject trends. Ultimately, the data she collected was used to develop a highly tuned approval plan to meet patron needs.

\section{Consortial Purchases}

The literature yielded several studies on consortial purchasing in the United States, from state-based groups such as OhioLINK, the Colorado University System, the California State University Library Consortium, the Arizona Universities Library Consortium, and the Consortium of Academic and Research Libraries in Illinois (CARLI), to large regional consortia such as the Orbis Cascade Alliance (OCA) and Association of Southeastern Research Libraries (ASERL). ${ }^{7}$ This literature review included only English language materials, limiting the diversity of international consortia; however, studies from Canadian and Chinese library consortia were discovered. ${ }^{8}$ Whether large regional or statewide, or small groups such as the Triangle Research Library Network (TRLN) or the Five College Consortium, many groups share similar goals, such as increasing buying power and providing broad access to research materials. ${ }^{9}$ Machovec's paper provides a comprehensive look into consortia, their histories, and goals. ${ }^{10}$

Pilot projects for Demand Driven Acquisition (DDA) and Patron Driven Acquisition (PDA) were prevalent, including examples from the OCA and Ontario Council of University Libraries (OCUL). OCA's DDA was discussed in an interview conducted by Jill Emery, collection 
development librarian, Portland State University. ${ }^{11}$ She interviewed members of OCA's Demand Driven Acquisitions (DDA) implementation team and their two vendor partners. The interview format provides a firsthand look into how various OCA members and their partners perceived the planning, implementation, and success of the project. While this paper provides a big picture perspective, Arch et al. describe in detail the process and factors in place that led to a successful consortial DDA plan with OCA members. ${ }^{12}$ They determined through a review of literature that very little has been published regarding the evaluation of large DDA programs, and the contribution of their work to the literature filled a gap with a detailed treatment of how the evaluation was conducted.

Davis et al. published a paper on OCUL's shared PDA experience. ${ }^{13}$ The authors reported that OCUL, a twentyone-member organization serving 420,000 users, attempted to develop a shared PDA program to meet the needs of individual schools, while maintaining a group shared cost benefit. Each perspective is presented; especially helpful are the vignettes from individual institutions detailing implementation concerns, usage, and rewards of the program.

\section{Big Deals}

Frazier, Bergstrom, and Nicholas et al. extensively addressed the Big Deal in prior years. ${ }^{14}$ Best, Gatten and Sanville, and Gibbs laid the foundation as early as 2004 for a shift away from Big Deals and have refocused the debate in 2012-13 on whether the Big Deal is dying. ${ }^{15}$ The University of California Libraries, the California Digital Library, Southern Illinois University-Carbondale, and the University of Oregon have cancelled Big Deals. ${ }^{16}$ McGrath discussed the efforts of a steering committee tasked with finding alternatives to the Big Deal by Research Libraries UK (RLUK), a consortium of research libraries in the United Kingdom. ${ }^{17}$ Despite efforts at some institutions to show less dependence on large journal packages, Big Deals have deeply penetrated the library market; Strieb and Blixrud reported on data collected from Association of Research Libraries (ARL) libraries and found that "three of four publishers covered in the two most recent surveys (Elsevier, Springer, and Wiley) are now licensed as bundles by $90 \%$ or more of libraries for which data were collected."18 The survey also found that Big Deal purchases are still commonly made through consortia, a factor which no doubt led authors Ashmore, Grogg, and Weddle to state "rumors of the Big Deal's death have been exaggerated." 19

An analysis of the literature suggests that the question should be further refined to "are serial Big Deals dying and big e-book deals flourishing?" Proctor notes that e-book Big Deals are mirroring what was seen in the e-journal market, namely desirable content packaged with low use materials, high costs, and little ability to choose titles included in a Big
Deal. ${ }^{20}$ Big Deals are not dying, and are evolving and may need to continue to evolve as alternatives are developed.

The Balance Point column, published in Serials Review, is a long-standing venue for experienced librarians to share individual perspectives on key issues in librarianship. One installment, edited by Dyas-Correia, consisted of interviews with representatives from small and large publishers, vendors, libraries, and consortia and asked if the Big Deal was on the way out. ${ }^{21}$ The panel agreed that there is a great deal of talk about cancelling Big Deals, but very few packages are actually canceled. In fact, the interview participants predicted that a large scale cancellation of Big Deal packages could permanently alter the role of consortia or cause their demise. Dooley noted, "If consortia members opt out, it could well increase cost for the remaining members, not to mention the effects on trust and good will." ${ }^{\prime 2}$ However, increasing costs and declining budgets are causing librarians to question the sustainability of purchasing all or a substantial portion of one publisher's content. Pay-Per-View (PPV), interlibrary loan (ILL), individual subscriptions, and Open Access models were suggested as alternatives to the Big Deal. Stanford University was cited as a model for meeting patron needs without subscribing to Big Deals. Van Rennes noted that "a little further down the line, I suspect that articles, rather than journals, will become the main unit of information commerce, and new models will be based upon that development." ${ }^{23}$ This could produce additional revenue streams for publishers in the area of PPV article models, small packages, and as Bucknell found at University of Liverpool, evidence-based selection. ${ }^{24}$

\section{Patron Driven Acquisitions (PDA)/Demand Driven Acquisitions (DDA)}

Interest in PDA continues to grow and implementations are widely documented, creating a robust body of published literature covering implementation issues, workflows, and evaluation. PDA plans are often executed as a way to realize cost savings, yet England and Anderson acknowledge that "PDA models do not necessarily lead to cost savings, but they do by their very nature forge a strong connection between acquisition and real-world usage, making PDA a potentially attractive model for libraries concerned about maximizing the effective use of their acquisition fund." ${ }^{25}$ This finding is consistent with other researchers, such as Dinkins and Schroeder, who have found that PDA selected materials enjoy excellent circulation. ${ }^{26}$

\section{Implementation}

Ward's book, Guide to Implementing and Managing PatronDriven Acquisitions, provides a complete how-to guide for implementing and managing a PDA model. ${ }^{27}$ Her coverage 
of PDA is inclusive as she describes ILL requests and patron catalog discoveries as points of triggered purchases. Chapter three covers issues to consider before implementing a PDA program, such as timing, PDA parameters, and determining who will be authorized to trigger purchases. Ward acknowledges criticisms and some of the challenges leveled against PDA in chapter six. Finally, she concludes with a discussion of future directions that includes the possibility of digitization on demand, print on demand, and the potential for collection development to be completely directed by patrons, potentially a new era in collection development. Allison's monograph, The Patron-Driven Library: A Practical Guide for Managing Collections and Services in the Digital Age, complements Ward's advice, providing information on the technological environment, challenges in library acquisitions, patron preferences, and other big picture topics. ${ }^{28}$

A case study by Fischer et al. documented the implementation of a completely unmediated e-book PDA plan at the University of Iowa Libraries that began in September 2009. ${ }^{29}$ The launch of the PDA plan was silent, the public was not informed to reduce bias or unreliable results during the evaluation of the pilot program. The authors found that during the trial, the allocation was quickly spent and they had to implement ways to control spending. Limits were not set to prevent format duplication, i.e., purchase of both print and electronic formats. Fischer et al. evaluated circulation rates for printtitlesthatwere duplicated byane-bookpurchasefrom the PDA plan and discovered that the circulation rate of print titles fell drastically once electronic equivalents were acquired.

McCaslin described a PDA program built on the Amazon Kindle platform at the California Institute of Technology. ${ }^{30}$ The library decided to circulate Kindles and provide patrons the authority to make $\$ 25$ in e-book purchases. The Kindle was chosen because the library could associate up to six devices with the library's controlled account, thereby providing access to the same selection of e-books on all Kindles. The library used Amazon gift cards linked to a library account to eliminate the financial risk involved with circulating a device linked to an open credit line. The paper covered details such as circulation, acquisitions policies, and accounting issues. A patron satisfaction questionnaire was distributed as part of the Kindle check-out process, and results indicated that most of the users were undergraduate students interested in reading previously selected material rather than purchasing new content, and there were many repeat users. The six month trial period, including staff time, startup costs, and book purchases cost $\$ 10,243.14$, a figure considered affordable by the library administration. ${ }^{31}$

\section{Evaluation of PDA/DDA}

Ongoing evaluation of the overall performance of PDA plans is needed to ensure value of this selection and purchasing method. Tyler et al. designed a study consisting of nonparametric statistical tests to evaluate PDA effectiveness, particularly investigating the factors that show favorable circulation over traditionally selected materials in prior studies. ${ }^{32}$ The authors found statistically significant differences in circulation rates between librarian-selected, vendor-selected, and patron-selected materials. The statistically significant result held even when the variables of book price, years available, and subject area were added to the model. The authors recommended continuing patron and librarian selection, while reducing the focus on vendor selection.

Walter's paper criticizes the value of PDA and considers it a risk to the long-term quality and ability of the library collection to meet the institution's educational mission. ${ }^{33}$ The author believes that librarians play an important role in the selection of materials and advocates mediating patron requests. This paper includes a chart comparing major PDA implementations in the literature. The chart includes data such as year started, vendor, number of titles made available, triggering thresholds, number of titles purchased annually and the price per title.

A case study conducted by McLure and Hoseth at Colorado State University examined a user survey and use statistics to produce a snapshot of patrons' attitudes regarding PDA. ${ }^{34}$ The library acquires a large portion of their e-books from the electronic PDA program, which is modified to include only a few select subjects. The authors discussed limitations of the survey, such as the brief online survey period and technological barriers that impacted the sample. The survey, set to pop up when a catalog record was viewed, asked if patrons had used e-books and whether they had a format preference, among other questions. The survey found an even split between those with no experience and experience using e-books. The survey showed " 29.22 percent preferring an e-book, 32.80 percent preferring a print book, and 37.98 percent indicating no preference." ${ }^{35}$ The authors used Dewey and LC subject headings analysis to gain an understanding of how faculty from various subject disciplines used the PDA model. The study concluded that most subjects were well served with PDA and the approval plans were reduced to cover a few select subjects.

\section{Evidence-Based Selection}

Bucknell described how the University of Liverpool (UOL) evaluated e-book packages and used modeling techniques to determine whether alternative acquisitions methods, such as PDA or DDA, were more cost effective than purchasing large e-book packages. ${ }^{36}$ UOL librarians typically did not engage in speculative book purchases, but a change in user demand for e-books prompted a modification in practice that allowed the purchase of e-book packages. Since this was a departure from routine practices, the librarians were interested in 
determining if there was an alternative way to meet patron demand while avoiding "just in case" collections. Bucknell modeled usage reports from purchased e-book packages to see if expenditures would have been higher with a PDA plan in place and found that the e-book package was more cost effective. Given this result, the next question is clearly how to identify what collections are most likely to be used. This is where evidence-based selection offers an opportunity to provide access to a large catalog of books and allows the library to buy books on the basis of consistent patron demand.

\section{Pay Per View}

In response to rapidly escalating prices and looming budget cuts, Hosburgh sought to mitigate the effect of journal cancelations, especially in the STEM area, by implementing both mediated and unmediated PPV models. ${ }^{37}$ PPV was established with three publishers and the new "Get It Now" program from the Copyright Clearance Center. Challenges such as expired tokens, duplicate purchases, incompatible vendor systems and link resolvers, and conflicting collection development philosophy, were addressed.

ReadCube, a new service providing journal article PDA has been evaluated by England and Anderson. They address ReadCube's business model and its trial at the University of Utah's Marriott Library during a one-year case study. ${ }^{38}$ While some feedback included negative experiences with DRM and the ReadCube client, they considered ReadCube to be a cost effective alternative to ILL. The novel approach discussed in this article is the acceptance of stringent digital rights management limitations in return for reduced costs.

An email thread on LIBLICENSE-L turned into a viable PPV model and the process was documented by Sowards. ${ }^{39}$ The conversation was geared toward solving frustrations with Big Deal pricing using a PPV model. The author noted that continued access to published research materials is a goal shared by librarians and publishers. Over the course of the year, the author worked with Multi-Science Publishing to create a PPV plan. The article meticulously details conversations that shaped the deal, providing an interesting look at how partnerships can be formed to solve common problems. As a final note, Sowards's literature review was well constructed and covers the depth of articles related to PPV, including four articles that merit more than a mere mention by Fisher, Kurt, and Gardner; Brown; Weicher and Zhang; and Powell. ${ }^{40}$

\section{Workflows}

\section{E-Books}

As e-book publishing grows, librarians have developed and refined workflows to meet patron demand. E-book workflows frequently involve multiple steps and intradepartmental collaboration, and are often not linear. Walter's bibliographic essay is an excellent review of published literature covering various impacts on e-book workflows including: availability of scholarly e-books, electronic publication delays, licensing, e-book file formats, pricing models, and preservation. ${ }^{41}$ While Walter's article focuses on challenges, the review is not negative and does not recommend abandoning e-book acquisition.

Building and Managing eBook Collections, edited by Kaplan, is the 184th installment in Neal-Schuman's How-ToDo-It Manuals series. This resource is an excellent addition to the literature because it provides a comprehensive collection of articles covering a wide range of topics in the management of e-book workflows. ${ }^{42}$ The first of three sections, "E-Books in Context," includes three chapters dedicated to outlining the history and development of e-books and e-book publishing from industry and library perspectives. The second section, "E-Books in Detail," covers practical areas of e-book management such as selection, licensing, budgeting, cataloging, and assessment. Six case studies of e-book implementations in high school, public, and academic libraries are included in the third section, "E-Books in Practice," covering topics including marketing, e-book readers, staff workflow for managing e-books at a university, and managing e-books in an ERM.

Roncevic's installment of the Library Technology Reports series, "E-book Platforms for Libraries," evaluated e-book platforms and provided a comprehensive resource for public, academic, and school librarians seeking information on where to purchase e-books. ${ }^{43}$ The author covered marketplace issues including corporate structure and business models and tied each business model to how it applies in public, academic, and school libraries. The bulk of the technology report is a comprehensive directory of e-book platforms available to libraries; the directory includes information such as target market, type of platform, type of e-book, subject, backgrounds, business model, and vendor websites. The last chapter provided comparative tables to give librarians a quick view so they can compare products against one another in such areas as scope, technical aspects, and business model.

Geller and Roscoe share the experience of selecting, processing, and circulating e-books on e-readers at Lesley University. ${ }^{44}$ After a selection process, the Apple iPad and Sony PRS-600 were chosen because a library policy prohibited purchasing materials from Amazon, eliminating the Kindle. The selection of e-book titles conformed to the library's collection development policies for two of their collections, New and Noteworthy and Casual Collections. While patron input was solicited, librarians were ultimately responsible for selection. Details regarding physical processing, circulation, and marketing were discussed, and 
there was an informative section titled "Lessons Learned." Among the lessons learned, the library discovered that the iPad was viewed as a versatile piece of equipment beyond its capability as an e-book reader. Patrons preferred the iPad, but some found the convenient size of the Sony reader to be better suited to e-book reading. Librarians at Lesley intend to purchase additional devices to provide library patrons with a broader selection of e-readers.

The complicated e-book workflows at the University of Tennessee library span six library units, requiring collaboration and standardization. Hodge, Manoff, and Watson discuss the issues and challenges faced in scaling up e-book purchasing to accommodate an e-preferred purchasing environment. ${ }^{45}$ Of particular complexity is the nonlinear nature of e-resource workflows with respect to licensing, invoicing, establishing access, and ensuring discoverability. The e-book workflow was prone to mistakes that could potentially cause purchased content to go undiscovered. To mitigate these problems, an E-Book Study Group was created to design clear and consistent workflows. Among the study group's recommendations was the implementation of a PDA program for e-books, addition of standardized language to record access terms and restrictions in MARC records, establishment and application of a minimum standard for record quality to MARC record batch-load processes, and elimination of redundant workflows. Workflows were designed, implemented, evaluated, and slowly evolved to ensure that e-books were available to library patrons.

Beisler and Kurt's case study conducted at the University of Nevada, Reno revealed that the complexity of e-book purchase models had grown, that there was an increased demand for e-books, and the workflow spanned multiple departments and was prone to communication breakdowns. ${ }^{46}$ In response, the University of Nevada, Reno assembled an interdepartmental task force to develop a new workflow and tracking system to address discoverability and technical service workflow inefficiencies. Significant challenges were communication breakdowns leading to undesirable outcomes, such as uncompleted licenses and improperly cataloged e-books. Workgroups were formed to focus on workflows, discovery, and ERM management issues. The authors outlined a series of questions to be addressed, which could be a helpful resource for any library developing or revising their e-book workflows. A request tracking system was created to provide key functions such as action item alerts, status update alerts, and a general communication tool. The system was used to gather supporting documents used by selection committees, licensing terms, and access information to ensure smooth customized workflows and efficient movement from ordering to discovery. The authors provided a detailed flowchart, visualizing the entire process from request to access. The task force's work enabled the University of Nevada, Reno libraries to create the necessary workflows for ensuring timely delivery of e-books purchased through a variety of acquisitions methods.

Duan and Grace outlined the e-book acquisitions workflow used at the Open University, a large online university based in the United Kingdom. ${ }^{47}$ With more than 200,000 distance education students, the e-book purchasing workflows must be efficient and serve the needs of the large student population. For Duan and Grace, a simpler method for buying e-books was through Big Deals, but they found a "long tail" of unused e-books, and excessive expenditures on "just in case books." The library service developed three tools to facilitate individual e-book purchases: (1) a series of questions to determine how a requested resource will be used, (2) a checklist of preferred options on vendor platforms, and (3) a database with a web form front end to track the purchase requests received from patrons. These tools work together to ensure that the library purchases e-books that match patron expectations.

\section{Streaming Video}

Duncan and Peterson describe their process for building a collection of streaming video by licensing content and employing fair use methods at the James Madison University library. ${ }^{48}$ The authors detail, with an emphasis on unique and complex issues, all the stages in a streaming video life cycle, including acquisition, access, administration, support, and evaluation. The acquisition stage mirrors other formats; however, due to the cost of streaming video titles, additional care is needed to make justifiable choices. The authors recommend careful evaluation of usage statistics and reliance on faculty requests to inform purchase decisions. Licensing can be complex because of the many options available, such as archival rights, performance rights, etc. In contrast, some publishers include simple use terms on an invoice in lieu of a license. The authors emphasize the importance of knowing what is being purchased and what type of licensing is involved, and tracking data in an ERM.

\section{Accounting and Budgeting}

Kirk's book, Balancing the Books: Accounting for Librarians, is a much needed guide on accounting topics for librarians. This monograph fills a gap in the literature, in library science education, and in continuing education. ${ }^{49}$ The first section discusses responsibilities of acquisition librarians and library directors as typically described in position descriptions. Librarians often find themselves responsible for accounting and budgeting, a need that has grown more acute with declining budgets that require librarians to project costs and track expenditures to prevent overspending. In this environment, training in accounting principles would enable librarians to effectively manage and balance library 
budgets. Kirk emphasized that outside of libraries, it is not common to assign responsibility for maintaining budgets to employees who lack formal training in accounting techniques. The author reviewed courses offered by sixty-three ALA-accredited library science programs and suggested that students interested in acquisitions and budgeting enroll in technical services and management courses.

The second section of Kirk's book provides detailed information about principles, philosophy, and practices followed in the field of accounting. Kirk introduces Generally Accepted Accounting Principles (GAAP), a framework of rules, adapted for different organizations, that ensures adherence to the basic elements of financial accounting. Also included is a highly informative discussion on accounting regulations, sample balance sheets, and general guidelines for federal, private, nonprofit, and publicly supported libraries. The chapter focuses on four themes: reporting by program, accounting for collections, accounting for investments, and the financial statement's relationship to budgets. ${ }^{50}$ The author introduced the Statement of Financial Accounting Concepts no. 8, a framework produced to document the context in which accounting takes place, define concepts, and outline the purpose of accounting. ${ }^{51}$ The final chapter of this section draws connections between library services and accounting practices. Financial accounting records provide proof of an organization's financial activity and need to be created and maintained with utmost accuracy and integrity. In-depth coverage of acquisitions ledgers created in ILSs is presented with an emphasis on planning the structure to match reporting requirements.

The final section of Kirk's book discusses budgeting from both a philosophical and practical perspective. The author asks readers to consider that budgeting is a plan for reaching goals, not a restrictive tool for monitoring the library's basic expenses. When creating a budget, librarians should develop a consistent narrative that will concisely justify budget requests in conjunction with a contingency plan for when requests are not fulfilled. Kirk also provides practical guidance on the principles of good budgeting: clarity, accuracy, consistency, and comprehensiveness. She suggests cultivating trend analyses and research to inform current and future budget projections and planning. Kirk includes common library budget challenges in her examples, offers suggestions for managing inflation, and poses considerations for cancellations.

Albitz and Brennan's book chapter, "Budgeting for E-Books," published in Building and Managing E-Book Collections: A How-To-Do-It Manual for Librarians, addresses the complex nature of purchasing models and the challenge of allocating funds to support PDA, subscriptions, one-time purchases, Big Deal e-book packages, and single firm order acquisitions. ${ }^{52}$ The authors make an interesting observation that unlike e-journal options, which started out as a free add-on feature to print subscriptions, e-books were always a separately sold product. Like e-journals, e-books are often sold with some type of continuing fee, as in the case of a subscription Big Deal for e-books, or a maintenance/platform fee for e-books purchased outright. Clearly, this diverges from print monograph acquisitions budgeting techniques, where an expense occurs once and the transaction is complete. The chapter discusses budgeting for PDA and ways to control costs, such as limiting the number of bibliographic records loaded into to the library catalog, placing cost limits, and implementing some form of librarian mediation of purchases. The chapter concludes with a brief discussion centered on strategies for funding e-book acquisitions, noting that while e-books have higher initial costs and represent a larger drain on collection budgets, studies have found that processing costs and staff time are reduced when moving to e-book acquisitions.

\section{Licensing}

Ashmore, Grogg, and Weddle's book, The Librarian's Guide to Negotiation, is a practical guide to developing negotiation skills. ${ }^{53}$ This book can help bridge the gap between what is covered in library school and the skills expected of an acquisitions professional. The first chapter introduces librarians to language used in business negotiations; techniques from well-known books such as The Power of Nice, Getting to Yes, and Start with No are reviewed and translated into terms relevant to librarians. The authors draw from the expertise of librarians, vendors, publishers, and consortia managers to compile practical advice, helpful checklists, and pointers. The experts urge librarians to address any anxieties, which likely emanate from the unknown, by reading library literature and seeking continuing education and mentorships.

Negotiation strategies to use in an economic downturn are outlined, including when it is appropriate to play hardball and how to do so in a respectful and productive manner. The concept of ordered flexibility, that is, knowing when and how to make a decisive action, is discussed as a tool for improving negotiation skills. Chapter 5 is written for librarians who negotiate with government officials for budget allocations, but many of the concepts can be applied broadly. Negotiating from a position of strength is important, and the authors note that strength is developed through comprehensive preparation. Strength is also built by becoming an active member in the community and being responsive to the community's needs.

The consolidation of publishers and vendors around a few large companies further exacerbates the challenges to successful negotiation for library materials. The authors remind librarians that they are not necessarily in weak negotiating positions simply because they are acquiring unique items, as academic libraries are the core customer base for 
many publishers. Chapter 7 provides strategies for negotiating in this environment, where Big Deals and monopoly-like competitive structures dominate. The authors point out that Big Deals offer an opportunity for strong negotiation, especially when done in collaboration with a consortium. While Big Deals may seem like a fixture, the authors cite the rejection of Big Deal packages by Cornell libraries and the Triangle Research Library Network consortium, and note that in a Big Deal negotiation, one of the most powerful tools is the ability to walk away.

Chapter 8 introduces the idea that negotiation does not end when a deal is finalized, and continues through into the management of acquired e-resources. This negotiation occurs internally between library staff members. Collins advises, "negotiation often manifests itself as management of political nuance, perception, and expectation with the organization. ${ }^{, 54}$ In a similar vein to chapter 8 , chapter 9 reminds readers that negotiations occur even in situations that do not involve financial resources. When using open source products, local expertise is often needed for successful implementation. This chapter covers negotiations for the costs associated with free resources such as implementation, maintenance, processing, and marketing. The authors also define open source and Open Access, and launch into an interesting discussion on negotiation in open communities.

Albitz and Brennan's book chapter, "Licensing of E-books," published in Building and Managing E-Book Collections: A How-To-Do-It Manual for Librarians, provides an overview of licensing issues of particular concern for e-books, such as platform choice, license types (i.e., unlimited user, nonlinear lending, single user), ILL terms, use terms, and preservation. ${ }^{55}$ The section on permitted uses, which differ from those for print books, is particularly helpful in understanding how copyright law applies to e-books. For example, the first sale doctrine does not apply equally to e-books, and may often be compromised by the terms of license agreements. ${ }^{56}$ The authors argue that in addition to legal issues, contract law limiting permitted uses is common because of the publisher concerns about piracy and a fundamental shift toward defining book chapters as the commodity.

The Primary Research Group regularly publishes surveys of topics relevant to acquisitions librarianship. The Survey of Scholarly Journal Licensing and Acquisition Practices published in 2012 presents a thorough account of questions and responses covering topics ranging from Big Deals to pricing and Open Access. ${ }^{57}$ The report details the research method and questionnaire and discusses the characteristics of the sample. The Survey of Library Database Licensing Practices, 2012 and 2013 editions, follows the same pattern of presenting detailed information on the research method, questionnaire and sample characteristics as well as providing valuable insight into database licensing practices..$^{58}$ Additionally, the report provides information on mobile device use, staff time dedicated to database management, and many other relevant topics.

\section{Acquisitions and Electronic Resource Management Tools}

\section{ERM Systems}

ERMs and how they can improve the e-resources workflow continue to be popular topics at the annual Charleston Conference. Appleton and Reagan investigated methods for streamlining workflows, with particular attention to using an automated alert system to improve communication and transparency in e-resources management. ${ }^{59}$ England, Fu, and Miller described their use of Six Sigma, a business process management solution. ${ }^{60}$ Six Sigma is based on a statistical method used to evaluate a process and make data driven improvements in quality by reducing the number of errors. ${ }^{61}$ By applying concepts from Six Sigma, the authors enabled small workflow adjustments resulting in improved patron satisfaction. Similarly, Brett, Castro, and Vacek discussed the importance of improving communication between various stakeholders in the e-resource acquisitions workflow through the use of a web portal. ${ }^{62}$ Langhurst, Marien, and Schmidt discussed the important work that occurs after an ERM implementation. ${ }^{63}$ The authors reported how the University of Notre Dame handled the post-development steps needed to align workflows with CORAL, an open source product created by Notre Dame's Hesburgh Libraries. ${ }^{64}$ For example, cataloging workflows fell outside of CORAL, prompting the development of an area of CORAL for tracking MARC record loads.

NASIG annual conferences featured several presentations discussing ERM implementations. ${ }^{65}$ England conducted a survey and found that librarians were managing local administrative data such as FTEs, internal contacts, and IP addresses with shared drives on computer networks. The presentation continued with a description of how England adapted an existing ERM record to store administrative data. McQuillan reported on the ERM Data Standards in Best Practices Review Steering Committee, a subgroup of the National Information Standards Organization (NISO). The author noted several areas that were under review, such as link resolvers and knowledge bases, work, manifestations, and access points; cost and usage related data license terms; and data exchange using institutional identifiers. ${ }^{66}$ McQuillan then discussed standards and other issues for each of the aforementioned categories; a paper outlining final recommendations can be obtained on the NISO webpage.$^{67}$ Imre, Hartnett, and Hiatt presented CORAL implementations from three different university libraries. Each author discussed the processes undertaken at their library, the selection, implementation, and future developments. What is most 
interesting about this paper is that the three implementations followed different paths, yet accomplished similar goals.

Hartnett et al. presented their experiences with implementing e-resource management systems; they detail two failed attempts and their success with CORAL. ${ }^{68}$ Texas A\&M (TAMU) is the flagship institution in a group of fourteen campuses, which required a system that could handle consortial purchases in addition to their own acquisitions. The library had intended to implement a commercial system, but the implementation team failed to make measurable progress and the ERM subscription was canceled. TAMU's next choice was the Gold Rush system created by the Colorado Alliance of Research Libraries, which lacked the robust features necessary to manage large collections. At this point, the library decided to follow a thorough selection process to avoid investing additional time in systems that failed to meet expectations. As the selection team reviewed the literature, implementation case studies, and vendor supplied data, CORAL quickly rose to the top of the pool. The authors then discuss the implementation of each module. The implementation team organized training sessions for everyone who would be required to use CORAL. Lastly, the authors sent a short survey to training session attendees and of eleven responses, five of the six respondents who have used CORAL since the training session are involved with e-resource management. The authors discovered that the intended target audience outside of e-resource management staff was not reached.

Jensen described the creation of an ERM system based on Google Sites implemented at the University of Alaska Fairbanks (UAF) ${ }^{69}$ The library used many technologies to manage their e-resources collections, including a commercial ERM, a trouble ticket system, a web-based database, spreadsheets, a network computer system, and email. The UAF library lacked a dedicated position for e-resources management and required a management system that was easy to access and capable of serving multiple library departments. The library first attempted to implement a system created using Drupal and found that the searching capabilities were not as robust as desired and various pieces of data generated during the e-resources life cycle were not integrated. The library then chose to move to a major vendor system, but discovered that the ERM was too difficult to use and lacked some of the necessary features. This led to the development of an ERM on Google Sites that met their e-resources management needs. The author discussed Google Sites' helpful features, including renewal notifications via Google Calendar, the ability to see site changes by looking at the revision history and create websites to share administrative information and document workflows, and most importantly, the presence of a Google search box. The Google Sites solution is also useful because it does not require specialized knowledge of computer programming to manage the ERM.

\section{Purchase Request Management Systems}

Many papers in the acquisitions field focus on the early stages of the acquisitions process, such as licensing and purchase models. Studies that address the final stages of the acquisitions process typically focus on usage statistics as a means of analyzing the effectiveness of purchasing models such as PDA or Big Deal packages. McMullen and Gray focus on the implementation of a service designed to inform requestors when the requested items are available in the library. ${ }^{70}$ The library had complicated, time-consuming, and antiquated protocols for generating PDF lists of new acquisitions from the ILS. Through a process of iterative changes, the library developed a current awareness service on an RSS feed platform. While this advancement was helpful, its major pitfall was the technology barrier that it presented to those unfamiliar with RSS feeds. The finalized service would allow requesters to track their requests through a department website dynamically generated by feeds from the ILS. This system requires catalogers to enter a four letter code from an existing system used to tie fund codes to academic departments in the ILS into a 945 MARC field, which is a field that can be locally customized. When placed in the 945 field, the codes created a unique text string used by a script designed to pull information from the ILS through the Z39.50 connections and publish it to a website. This system allows requesters to track their books after the order was placed even if a book falls outside the discipline normally requested. This is accomplished by using the 945 field to note the requester's department, rather than the book's subject. The authors found that the current awareness service was well used, as indicated by Google Analytics and anecdotal evidence.

Downey described Kent State University Libraries' implementation of a locally designed system, named PreILS, to manage the steps of an e-resource workflow that occurs before a record is created in an ILS. ${ }^{71}$ One of the complaints Pre-ILS addressed was the avalanche of emails required to move an e-resource request through the trial to access process. The library had used many disparate systems including the ERM, ILS, spreadsheets, and email, and cobbled them together to manage the workflow in a way that was prone to communication breakdowns. Several meetings were convened to develop working requirements for the system and to plan the development and implementation of Pre-ILS. The system is intended to be used by selectors as a place to request pricing information, review resources, store trial feedback, and approve purchases. As a resource moves through the acquisition stages, each stakeholder is notified of progress. An interesting feature of the system is the ability to offer five different levels of user access, from level one (view-only access open to the public) through level five (access reserved for decision-makers). Pre-ILS was not developed on an open platform and cannot be easily shared. 
Yang and Hung, affiliated with the Department of Information Management at Nanhua University, Taiwan, developed an innovative approach to gathering patrons' book recommendations through data mining and algorithm development. ${ }^{72}$ The authors noted in their technical paper that book recommendation workflows are often complicated and require significant staff intervention causing long waits for books, and are often not well marketed to patrons. The authors created an innovative electronic system that uses text mining of user search input from failed searches in the library catalog and generates a purchase list from the mined data. The recommended prototype was well tested and appeared to be an innovative method for mining patron search queries to create a recommend for purchase list.

\section{Conclusion}

Purchasing models saw rapid changes in the period from 2012-13, generating several publications. Interest in firm order purchasing and approval plans waned during this review period, and was refocused on consortial purchases, PDA, and DDA. Consortial purchasing is a popular topic in the literature covering Big Deal packages and PDA/DDA pilot programs. While some libraries, such as the University of California Libraries and Southern Illinois UniversityCarbondale have cancelled Big Deals, ARL surveys have revealed the deep and persistent presence of Big Deals in the library market, especially in the consortial arena. Interest in PDA and DDA continues to grow and implementation reports are widely shared, creating a robust body of published literature. As this literature review has shown, studies have been conducted to determine the utility of PDA. Many have found that PDA offers a way for libraries to allow direct input from patrons in the selection of materials, which often has a positive impact on circulation rates and has been used as a tool to control spending. PDA models have evolved to include e-book readers such as the Amazon Kindle. The literature has also demonstrated a growing interest in Evidence-Based Selection as an alternative to PDA, and PPV programs such as ReadCube and "Get it Now" as alternatives to Big Deal packages.

Advancing technology has proven to be a challenge and opportunity in the acquisitions field. The challenges include: increasingly complicated workflows, licensing challenges, rising interest in e-books on dedicated e-reader devices, growing reliance on streaming media, and an expanding array of purchase models for electronic content. These challenges have opened opportunities to leverage technology to improve workflows and ultimately patron satisfaction through the acquisition and delivery of needed research materials. Innovative solutions include the pre-ILS system developed at Kent State University, an ERM system built on Google Sites, and a book acquisitions recommendation model developed at the University of Taiwan. ${ }^{73}$ CORAL implementations are commonly discussed in the literature and 2012-13 saw growing interest in improving CORAL and improving workflows with the goal of increasing efficiency and in turn improving patron satisfaction. An underlying theme of library technology is the basic need to improve communications, whether it be between library employees, vendors, or patrons. New purchasing models require new workflows and new workflows necessitate the development of workflow management tools. This literature review has shown how these areas are interconnected and growing.

\section{References and Notes}

1. Barbara S. Dunham and Trisha L. Davis, "Literature of Acquisitions Review, 1996-2003," Library Resources o Technical Services 52, no. 4 (2008): 238-53, http://dx.doi .org/10.5860/lrts.52n4.238; Barbara S. Dunham and Trisha L. Davis, "Literature of Acquisitions Review, 2004-7," Library Resources \& Technical Services 53, no. 4 (2011): 231-42, https://journals.ala.org/lrts/article/view/5181/6287; Jeanne Harrell, "Literature of Acquisitions Review, 20089," Library Resources \& Technical Services 56, no. 1 (2012): 4-13, https://journals.ala.org//rts/article/view/5493/6740; Paul D. Moeller, "Literature of Acquisitions Review, 2010-11," Library Resources \& Technical Services 57, no. 2 (2013): 87-99, http://dx.doi.org/10.5860/lrts.57n1.87.

2. Moeller, "Literature of Acquisitions Review, 2010-11," 87-99.

3. Tony G. Horava, "Direct Ordering by Subject Librarians in a Vendor System: A Case Study," Partnership: The Canadian Journal of Library \& Information Practice \& Research 7, no. 1 (2012): 1-11, https://journal.lib.uoguelph.ca/index.php/perj/ article/view/1723/2472\#.VgAO5t9VhBc.

4. Rita M. Cauce, "Where's Professor Watt's Request? Streamlining to a Paperless Acquisitions Workflow," in Something's Gotta Give: Charleston Conference Proceedings, 2011, edited by Beth R. Bernhardt, Leah H. Hinds, and Katina P. Strauch (West Lafayette: Purdue University Press, 2012), 446-49.

5. Sarah Forzetting, Gabrielle Wiersma, and Leslie Eager, "Managing E-Book Acquisition: The Coordination of 'P' and 'E' Publication Dates," Serials Librarian 62, no. 1-4 (2012): 200-205, http://dx.doi.org/10.1080/0361526X.2012.652921.

6. Gabrielle Wiersma, "What's the Delay? Managing E and P Publication Dates," Library Collections Acquisitions, d Technical Services 37, no. 1 (2013): 13-18, http://dx.doi .org/10.1016/j.lcats.2013.03.001.

7. Rob Kairis, "A Subject-Based Shared Approval Plan for Consortia Purchasing of US University Press Books," Library Collections, Acquisitions, \& Technical Services 36, no. 1 (2012): 30-38, http://dx.doi.org/10.1016/j.lcats.2012.03.002; Wen-Ying Lu and Mary Beth Chambers, "PDA Consortium Style," Library Resources \& Technical Services 57, 
no. 3 (2013): 164-78, http://dx.doi.org/10.5860/lrts.57n3.164; Jodi Shepherd and Marc Langston, "Shared Patron Driven Acquisition of E-Books in the California State University Library Consortium," Library Collections Acquisitions \& Technical Services 37, no. 1-2 (2013): 34-41, http:// dx.doi.org/10.1016/j.lcats.2013.08.001; Jeanne Richardson, "The Arizona Universities Library Consortium Patron-Driven E-Book Model," Insights: The UKSG Journal 26, no. 4 (2013): 66-69, http://dx.doi.org/10.1629/2048-7754.26.1.66; Lynn Wiley and Elizabeth Clarage, "Building on Success: Evolving Local and Consortium Purchase-on-Demand Programs," Interlending \& Document Supply 40, no. 2 (2012): 105-10, http://dx.doi.org/10.1108/02641611211239588; Jill Emery, "The Demand Driven Acquisitions Pilot Project by the Orbis Cascade Alliance: An Interview with Members of the Demand Driven Acquisitions Implementation Team," Serials Review 38, no. 2 (2012): 132-36, http://dx.doi .org/10.1016/j.serrev.2012.04.008; Xan Arch et al., "By Popular Demand: Building a Consortial Demand-Driven Program," in Something's Gotta Give: Charleston Conference Proceedings, 2011, edited by Beth R. Bernhardt, Leah H. Hinds, and Katina P. Strauch (West Lafayette: Purdue University Press, 2012); Connie Stovall, Leslie O'Brien, and Edward Lener, "Virginia Tech's Participation in ASERL's Cooperative Print Journal Retention Project" in Something's Gotta Give: Charleston Conference Proceedings, 2011, edited by Beth R. Bernhardt, Leah H. Hinds, and Katina P. Strauch (West Lafayette: Purdue University Press, 2012).

8. Kate Davis et al., "Shared Patron-Driven Acquisition within a Consortium: The OCUL PDA Pilot," Serials Review 38, no. 3 (2012): 183-87, http://dx.doi.org/10.1016/j .serrev.2012.08.002; Tony Horava, "Today and in Perpetuity: A Canadian Consortial Strategy for Owning and Hosting Ebooks," Journal of Academic Librarianship 39, no. 5 (2013): 423-28, http://dx.doi.org/10.1016/j.acalib.2013.04.001; Xiaoxia Yao, "Evaluation and Promotion: The Cooperative Purchase Experience of Academic Libraries in China," Library Collections, Acquisitions, \& Technical Services 36, no. 3 (2012): 97-106, http://dx.doi.org/10.1016/j.lcats.2012.05.003.

9. Sarah Kalikman Lippincott et al., "Librarian, Publisher, and Vendor Perspectives on Consortial E-Book Purchasing: The Experience of the TRLN Beyond Print Summit," Serials Review 38, no. 1 (2012): 3-11, http://dx.doi.org/10.1016/j .serrev.2011.12.003; Leslie Button et al., "Reducing Unintentional Duplication: Adventures and Opportunities in Cooperative Collection Development," in Something's Gotta Give: Charleston Conference Proceedings, 2011, edited by Beth R. Bernhardt, Leah H. Hinds, and Katina P. Strauch (West Lafayette: Purdue University Press, 2012).

10. George Machovec, "Library Consortia: The Big Picture," Journal of Library Administration 53, no. 2-3 (February 2013): 199-208, http://dx.doi.org/10.1080/01930826.2013.8 53504 .
11. Jill Emery and Bonnie Parks, "The Demand Driven Acquisitions Pilot Project by the Orbis Cascade Alliance: An Interview with Members of the Demand Driven Acquisitions Implementation Team," Serials Review 38, no. 2 (June 2012): 132-36, http://dx.doi.org/10.1016/j.serrev.2012.04.008.

12. Xan Arch et al., "By Popular Demand."

13. Davis et al., "Shared Patron-Driven Acquisition within a Consortium," 183-87.

14. Kenneth Frazier, "What's the Big Deal?," Serials Librarian 48, no. 1 (2005): 49-59, http://dx.doi.org/10.1300/ J123v48n01_06; Theodore C. Bergstrom, "Librarians and the Terrible Fix: Economics of the Big Deal," Serials 23, no. 2 (2010): 77-82, http://search.proquest.com.jproxy.lib .ecu.edu/docview/753822310?accountid=10639; David Nicholas et al., "What Deep Log Analysis Tells Us about the Impact of Big Deals: Case Study OhioLINK," Journal of Documentation 62, no. 4 (2006): 482-508, http://dx.doi .org/10.1108/00220410610673864.

15. Jeffrey N. Gatten and Tom Sanville, "An Orderly Retreat from the Big Deal: Is it Possible for Consortia?," D-Lib Magazine 10, no. 10 (2004), www.dlib.org; Rickey D. Best, "Is the "Big Deal” Dead?," Serials Librarian 57, no. 4 (2009): 35363, http://search.proquest.com.jproxy.lib.ecu.edu/docview/5 7691425? accountid=10639; Nancy J. Gibbs, "Walking Away from the 'Big Deal': Consequences and Achievements," Serials 18, no. 2 (2005): 89-93, http://search.proquest.com.jproxy lib.ecu.edu/docview/57614754?accountid=10639.

16. "UC Libraries Discontinue Taylor \& Francis Systemwide Journals License," California Digital Library website, July 3, 2013, accessed December 27, 2015, www.cdlib.org/cdlinfo/ 2013/07/03/uc-libraries-discontinue-taylor-francis-systemwide -journals-license/; Jonathan Nabe and David C. Fowler, "Leaving the 'Big Deal': Consequences and Next Steps," Serials Librarian 62, no. 1-4 (2012): 59-72, http://dx.doi.org/10.1 080/0361526X.2012.652524.

17. Mike McGrath, "Fighting Back Against the Big Deals: A Success Story from the UK," Interlending of Document Supply 40, no. 4 (2012): 178-86, http://dx.doi.org/ $10.1108 / 02641611211283831$.

18. Karla L. Strieb and Julia C. Blixrud, "The State of Large-Publisher Bundles in 2012," Research Library Issues: A Report from ARL, CNI, and SPARC no. 282 (2013): 13-20, http:// publications.arl.org/rli282.

19. Beth Ashmore, Jill E. Grogg, and Jeff Weddle, The Librarian's Guide to Negotiation Winning Strategies for the Digital Age (Medford: Information Today, 2012), 144.

20. Julia Proctor, "Avoiding Ebook 'Big Deals": Alternatives to Ebook Backlists," New Library World 114, no. 7-8 (2013): 301-7, http://dx.doi.org/10.1108/NLW-02-2013-0018.

21. Robert W Boissy et al., "Is the 'Big Deal' Dying?," Serials Review 38, no. 1 (2012): 36-45, http://dx.doi.org/10.1016/j serrev.2011.12.012.

22. Ibid., 42 . 
23. Ibid., 41.

24. Terry Bucknell, "Buying by the Bucketful: A Comparative Study of E-Book Acquisition Strategies," Insights: The UKSG Journal 25, no. 1 (2012): 51-60, http://dx.doi .org/10.1629/2048-7754.25.1.51.

25. Mark England and Rick Anderson, "Patron-Driven Acquisition of Journal Articles Using ReadCube at the University of Utah," Insights: The UKSG Journal 26, no. 3 (2013): 267-71, http://dx.doi.org/10.1629/2048-7754.77.

26. Debbi Dinkins, "Individual Title Requests in PDA Collections: A Small University Library's Experience," College d Research Libraries News 73, no. 5 (2012): 249, http://crln .acrl.org/content/73/5/249.full.pdf+html; Rebecca Schroeder, "When Patrons Call the Shots: Patron-Driven Acquisition at Brigham Young University," Collection Building 31, no. 1 (2012): 11-14, http://dx.doi.org/10.1108/01604951211199128.

27. Suzanne M. Ward, Guide to Implementing and Managing Patron-Driven Acquisitions (Chicago: ALCTS, 2012).

28. Dee Ann Allison, The Patron-Driven Library: A Practical Guide for Managing Collections and Services in the Digital Age (Oxford: Chandos, 2013).

29. Karen S. Fischer et al., "Give 'Em what they Want: A OneYear Study of Unmediated Patron-Driven Acquisition of E-Books," College \& Research Libraries 73, no. 5 (2012): 469492, http://dx.doi.org/10.5860/crl-297.

30. David McCaslin, "Collection Building through Patrons: Caltech Library's Kindle Program," Collection Management 38, no. 3 (2013): 172-91, http://dx.doi.org/10.1080/01462679 .2013 .792308

31. Ibid., 83.

32. David C. Tyler et al., "Patron-Driven Acquisition and Circulation at an Academic Library: Interaction Effects and Circulation Performance of Print Books Acquired Via Librarians' Orders, Approval Plans, and Patrons' Interlibrary Loan Requests," Collection Management 38, no. 1 (2013): 3-32, http://dx.doi.org/10.1080/01462679.2012.730494.

33. William H. Walters, "Patron-Driven Acquisition and the Educational Mission of the Academic Library," Library Resources \& Technical Services 56, no. 3 (2012): 199-213, http://dx.doi .org/10.5860/lrts.56n3.199.

34. Merinda McLure and Amy Hoseth, "Patron-Driven E-Book use and Users' E-Book Perceptions: A Snapshot," Collection Building 31, no. 4 (2012): 136-47, http://dx.doi.org/ 10.1108/01604951211274043.

35. Ibid., 139.

36. Bucknell, "Buying by the Bucketful," 51-60.

37. Nathan Hosburgh, "Getting the Most Out of Pay-Per-View: A Feasibility Study and Discussion of Mediated and Unmediated Options," Journal of Electronic Resources Librarianship 24, no. 3 (2012): 204, http://dx.doi.org/10.1080/194112 6X.2012.706112.

38. England and Anderson, "Patron-Driven Acquisition of Journal Articles," 267-71.
39. Steven W. Sowards, "Library-Publisher Experimentation and Partnership in Alternative Models for Journal Content," The Serials Librarian 65, no. 3-4 (2013): 309, http://dx.doi.org/10 .1080/0361526X.2013.837858.

40. Erin S. Fisher, Lisa Kurt, and Sarah Gardner, "Exploring Patron-Driven Access Models for E-journals and E-books," Serials Librarian 62, no. 1-4 (2012): 164-68, http://dx.doi.org/ 10.1080/0361526X.2012.652913; Heather L. Brown, "PayPer-View in Interlibrary Loan: A Case Study," Journal of the Medical Library Association: JMLA 100, no. 2 (2012): 98-103, http://dx.doi.org/10.3163/1536-5050.100.2.007; Maureen Weicher and Tia Xiao Zhang, "Unbundling the 'Big Deal' with Pay-Per-View of E-Journal Articles," Serials Librarian 63, no. 1 (2012): 28, http://dx.doi.org/10.1080/0361 526X.2012.688167; Allen Powell, "Navigating the New Norm: Vendor, Publisher, and Librarian Strategies to Cope with the Changing Information Industry," Journal of Library Administration 52, no. 5 (2012): 370, http://dx.doi.org/10.1080/0193 0826.2012 .701112 .

41. William H. Walters, "E-Books in Academic Libraries: Challenges for Acquisition and Collection Management," portal: Libraries of the Academy 13, no. 2 (2013): 187-211, http:// dx.doi.org/10.1353/pla.2013.0012.

42. Richard Kaplan, ed., Building and Maintaining E-Book Collections: A How-To-Do-It Manual for Librarians (Chicago: Neal-Schuman, 2012).

43. Mirela Roncevic, "E-book Platforms for Libraries," Library Technology Reports 49, no. 3 (2013): 5-43, https://journals .ala.org/ltr/issue/view/130.

44. Marilyn Geller and Linda Roscoe, "Accessing and Circulating E-Books with E-Readers-Lesley University," in Building and Managing E-Book Collections: A How-To-Do-It Manual for Librarians, edited by Richard Kaplan (Chicago: NealSchuman, 2012), 171-76.

45. Valeria Hodge, Maribeth Manoff, and Gail Watson, "Providing Access to E-Books and E-Book Collections: Struggles and Solutions," Serials Librarian 64, no. 1-4 (2013): 200-205, http://dx.doi.org/10.1080/0361526X.2013.760411.

46. Amalia Beisler and Lisa Kurt, "E-Book Workflow from Inquiry to Access: Facing the Challenges to Implementing E-Book Access at the University of Nevada, Reno," Collaborative Librarianship 4, no. 3 (2012): 96-116, http://collaborativelib rarianship.org/index.php/jocl/article/viewArticle/188.

47. Sharon Duan and Claire Grace, "E-Book Purchasing: The Open University's Experience," Insights: The UKSG Journal 26, no. 3 (2013): 250-55, http://dx.doi.org/10.1629/2048 -7754.100 .

48. Cheri Duncan and Erika Peterson, "You Ought to be in Pictures: Bringing Streaming Video to Your Library," in Something's Gotta Give: Charleston Conference Proceedings, 2011, ed. Beth R. Bernhardt, Leah H. Hinds, and Katina P. Strauch (West Lafayette: Purdue University Press, 2012).

49. Rachel A. Kirk, Balancing the Books: Accounting for 
Librarians (Santa Barbara: Libraries Unlimited, 2013).

50. Ibid., 45.

51. Financial Accounting Standards Board, "Statement of Financial Accounting Concepts No. 8," accessed September 19, 2015, www.fasb.org/jsp/FASB/Document_C/DocumentPage ?cid=1176157498129\&acceptedDisclaimer=true.

52. Becky Albitz and David Brennan, "Budgeting for E-Books," in Building and Managing E-Book Collections: A How-ToDo-It Manual for Librarians, edited by Richard Kaplan (Chicago: Neal-Schuman, 2012), 85-94.

53. Beth Ashmore, Jill E. Grogg, and Jeff Weddle, The Librarian's Guide to Negotiation Winning Strategies for the Digital Age (Medford, NJ: Information Today, 2012).

54. Ibid., 168.

55. Becky Albitz and David Brennan, "Licensing of E-Books," in Building and Managing E-Book Collections: A How-To-Do-It Manual for Librarians, edited by Richard Kaplan (Chicago: Neal-Schuman, 2012), 75-84.

56. Rachel Ann Geist, “A 'License to Read': The Effect of E-books on Publishers, Libraries, and the First Sale Doctrine," Idea 52, no. 1 (2012): 63-100, http://ipmall.info/hosted _resources/IDEA/idea-vol52-nol-geist.pdf.

57. Primary Research Group, Survey of Scholarly Journal Licensing and Acquisition Practices (New York: Primary Research Group, 2012).

58. Primary Research Group, Survey of Library Database Licensing Practices (New York: Primary Research Group, 2012); Primary Research Group, Survey of Library Database Licensing Practices (New York: Primary Research Group, 2013).

59. Betsy Appleton and Shannon Regan, "Going Beyond Electronic Resource Management System (ERMS) Implementation: ERMS-Focused Work flows and Communications," in Something's Gotta Give: Charleston Conference Proceedings, 2011, edited by Beth R. Bernhardt, Leah H. Hinds, and Katina P. Strauch (West Lafayette: Purdue University Press, 2012).

60. Lenore England, Stephen Miller, and Li Fu, "Optimizing Your ERM: Application of Business Process Management to Operations," in Something's Gotta Give: Charleston Conference Proceedings, 2011, edited by Beth R. Bernhardt, Leah H. Hinds, and Katina P. Strauch (West Lafayette: Purdue University Press, 2012).

61. More information about Six Sigma can be found at http://asq .org/learn-about-quality/six-sigma/tools.html.

62. Kelsey Brett, Jeanne M. Castro, and Rachel Vacek, "How to Build a Better Mousetrap: Developing an Easy, Functional ERM" in Accentuate the Positive!: Charleston Conference Proceedings, 2012, edited by Beth R. Bernhardt, Leah H. Hinds, and Katina P. Strauch (West Lafayette: Purdue University Press, 2012).

63. Andrea Langhurst, Stacey Marien, and Kari Schmidt, "Beyond Implementation: Making Your ERMS Work for You" in Accentuate the Positive!: Charleston Conference
Proceedings, 2012, edited by Beth R. Bernhardt, Leah H. Hinds, and Katina P. Strauch (West Lafayette: Purdue University Press, 2012).

64. More information about CORAL can be found at http://coral -erm.org/about.

65. Bob McQuillan, "Gateway to Improving ERM System Deliverables: NISO ERM Data Standards and Best Practices Review," Serials Librarian 62, no. 1-4 (2012): 112-24, http:// dx.doi.org/10.1080/0361526X.2012.652482; Deborah England, "We have our ERM System, it's Implemented: Why Am I Still Going here and there to Get the Information I Need?" Serials Librarian 64, no. 1-4 (2013): 111, http://dx.doi.org /10.1080/0361526X.2013.760148; Andrea Imre, Eric Hartnett, and C. Derrik Hiatt, "CORAL: Implementing an OpenSource ERM System," Serials Librarian 64, no. 1-4 (2013): 224, http://dx.doi.org/10.1080/0361526X.2013.760414.

66. McQuillan, "Gateway to Improving ERM System Deliverables,"114.

67. NISO ERM Data Standards and Best Practices Review Steering Committee, Making Good on the Promise of ERM: A Standards and Best Practices Discussion Paper (Baltimore: NISO, 2012), www.niso.org/apps/group_public/download .php/7946/Making_Good_on_the_Promise_of_ERM.pdf.

68. Eric Hartnett et al., "Charting a Course Through CORAL: Texas A\&M University Libraries' Experience Implementing an Open-Source Electronic Resources Management System," Journal of Electronic Resources Librarianship 25, no. 1 (2013): 16-38, http://dx.doi.org/10.1080/194112 6X.2013.760402.

69. Karen Jensen, "Managing Library Electronic Resources Using Google Sites," Journal of Electronic Resources Librarianship 25, no. 2 (2013): 115-23, http://dx.doi.org/10.1080/19 41126X.2013.785289.

70. Anthony McMullen and Barry Gray, "From Static to Dynamic: Using the OPAC to Generate Real-Time Lists of Departmental Acquisitions for Library Current Awareness Service," Library Hi Tech 30, no. 4 (2012): 673-82, http://dx.doi .org/10.1108/07378831211285121.

71. Kay Downey, "Kent State University Libraries Develops a New System for Resource Selection," in Something's Gotta Give: Charleston Conference Proceedings, 2011, edited by Beth R. Bernhardt, Leah H. Hinds, and Katina P. Strauch (West Lafayette: Purdue University Press, 2012).

72. Shih-Ting Yang and Ming-Chien Hung, "A Model for Book Inquiry History Analysis and Book-Acquisition Recommendation of Libraries," Library Collections, Acquisitions, \& Technical Services 36, no. 3 (2012): 127-42, http://dx.doi .org/10.1016/j.lcats.2012.05.001.

73. Downey, "Kent State University Libraries Develops a New System for Resource Selection," 157-62; Shih-Ting Yang and Ming-Chien Hung, "A Model for Book Inquiry History Analysis and Book-Acquisition Recommendation of Libraries," 127-42. 